\title{
Investigation of Teacher Candidates' Opinions about Instructional Technologies and Material Usage*
}

\author{
Hanife Gülhan Orhan-Karsak \\ Correspondence: Hanife Gülhan Orhan-Karsak, Asst. Prof. Dr., Department of Education Sciences, Science-Literature \\ Faculty, Kirklareli University, Kirklareli, Turkey.
}

Received: March 20, 2017

doi:10.11114/jets.v5i5.2286
Accepted: April 21, $2017 \quad$ Online Published: April 27, 2017

URL: https://doi.org/10.11114/jets.v5i5.2286

\begin{abstract}
The purpose of this study is to determine the awareness of teacher candidates about instructional technologies and materials and the ways of giving place in instruction by integrating them with different activities, to reveal opinions about their usage. Seventeen female and eight male, in total twenty five participants are sampling. The ages of the participants within the group heterogeneous between twenty two and thirty five.

According to the purpose, the opinions of the teachers candidates who have been taken 'Instructional Technology and Material Design' lesson in the 'Pedagogical Formation Training Certificate Program' which is a pre-service teacher training program and have been practiced learning outputs of this lesson in other practical instruction lessons and in their lectures in the teaching internship school, were taken by writing. In this context the study is designed as a qualitative research. The findings are presented in thematically coded and supported by mind maps as visuals.

It has been seen that teacher candidates are focused on different instructional technologies and materials that they learned in the 'Instructional Technology and Material Design' lesson. In addition different experiences of teacher candidates about the usage of instructional technologies and materials have been identified.
\end{abstract}

Keywords: instructional materials, instructional material design, teacher candidate, instructional technologies, opinions

\section{Introduction}

Today, we are looking for ways to improve the quality of instruction every day. In order to achieve this goal, it is shown that trying to reach different characteristics of learners, to use different instructional methods and techniques and different designed learning environments.

According to changing and developing technology, another component that will enhance the quality of instruction is to integrate instruction with different instructional materials and technologies. The development of instructional materials and technologies has made it necessary for teacher candidates to be expert in information literacy and new instructional technologies.

In this context, the competence of utilizing instructional technologies is provided possibilities to teacher candidates for using computers in instruction and taking advantages of software applications and other technological tools.

Teachers who are expert in information literacy are expected to have the ability to use instructional technologies for this purpose and to be inclined to develop these skills (Altun, 2005). The process of submitting information from the sources of the multiplicity of knowledge and providing the service desired by the student now exceeds the teacher's own efforts.

Due to rapidly changing and developing technology, learning theories, instructional methods and techniques, a wide variety of instructional materials and instructional technologies are needed to support both in-class and out-of-class work.

From this point on, the teacher has to consider about the technology and the materials to be used and the benefits that students will gain from these resources while making the instructional design according to individual characteristics (Ceyhan, 2007). The use of instructional materials and software should allow students to take more of their own responsibilities as compared to traditional environments and that the teacher should take the role of a coach in this process (Duffy \& Jonassen, 1992). With all, the role of the teacher in the utilization efficiency of instructional

\footnotetext{
*This article presented as a paper and published as an abstract paper in VIII. International Congress of Educational Research, May 5-8, 2016, Çanakkale Onsekiz Mart University, Çanakkale, Turkey.
} 
technologies makes a difference (Postholm, 2007). In addition, teachers should be able to use every possible opportunity to interact with technology in order to effectively prepare students for the future (Tomei, 2013).

Besides, the software enables the teacher to implement an instruction which adresses different types of intelligence and learning styles (Grasha \& Yangarber- Hicks, 2000), individual differences and learning speeds and allow to take care of one's individual. Thus, softwares offer the oppurtunity to integrate students with the learning process easily and move away from the traditional environment. But today, instructional technologies, especially computers and softwares, are still not sufficiently integrated with the teaching process. It is usually used to write reports related to the instructional process, to research on the internet, to play games and enter evaluation data, to make more qualified lesson plans, to communicate more with families through e-mails and blogs. Of course, these applications are also needed but are limited and inadequate for today. It is necessary that instructional technologies should be transferred into instructional implementations.

Moreover, web tools such as social networks for disadvantaged students, especially those with learning difficulties or who can not participate in the school environment for different reasons, are also required (Christensen, Horn, Johnson, 2008). For these reasons, it is a need for teacher candidates to have the competence to integrate instructional technologies and materials in a meaningful way. In an appropriate learning environment, integrating instructional technologies and materials with methods and techniques which are in accordance with the gains, is a requirement for teacher candidates. Also it is significant to be able to guide students during the implementation process. Because as Ceyhan (2007) stated, a lesson in which a one-way form of communication and one-way stimulants are used and where instructional materials and technologies are not included, will become ineffective and unbearable.

In this context, teachers who know their students' personal and learning characteristics, boundaries, requests and needs better than commercial material developers (Sarıçoban et al., 2012), acquire competence to develop instructional materials which are suitable for the students' characteristics, needs and subjects. Additionally it is important for teachers to acquire competence to integrate materials with issues that related their subject, to consider about the types of usage and to plan all of them effectively. This competence will increase as teacher candidates are open to learning about usage of instructional technologies and materials, as noted by Baylor and Ritchie (2002) in their research's conclusions. Nevertheless, when teachers increase their competencies in usage, their morale levels and teaching productivity will increase and their students' thinking skills will be improved.

The instructional material generally covers the contents of course presentations made using the tools to achieve the goal (Yanpar-Yelken, 2014). Instructional tools are the materials used for convenience for teaching and learning purposes (Sever, 2011). Teaching tools can be two-dimensional visuals like pictures, drawings, graphics, schedules, posters, concept maps, cartoons as well as three-dimensional visuals such as real objects, models, visual instruments in the form of various kinds of boards or audio devices such as radio, cd and audiovisual devices such as television and video (Ekici et. al., 2014). Nowadays these tools are available through different technological tools such as Animoto, Glogster and flip video cameras (De- Lay, 2010). Simply, for example, the writing board is a tool. It becomes a lesson material when a writing, an image and a process are created with a board pencil on it (Yanpar-Yelken, 2014). The concept of instructional technology is a medium containing television, computers, projectors, films, hardware and software elements, which are caused by radical changes in communication used for teaching purposes as well as teacher, lesson notes and blackboard. In other words, instructional technology can be explained by the integration of audiovisual devices, individualized teaching, a system approach in which all of the learning and teaching process is designed, conducted and evaluated (Gagne, 2010).

Effective use of instructional materials and technologies is very important in order to make the planned gains permanent for the students. In this context, the effective use of instructional materials and technologies can be achieved by teacher as integrating attention, motivation and preliminary observations at the entrance of the teaching period, integrating appropriately with methods and techniques in the lesson of the process, and finally summarizing and measuring and evaluating the lesson. Effective fulfillment of these aims, however, requires that effective benefit of the "Instructional Technology and Material Design" lesson for teacher candidates when they have taken during their university years. In addition professional development of the teacher candidates needs to continue to develop with in-service training and their personal efforts.

For these reasons, according the decision of the 'Council of Training and Education' of the 'Ministry of National Education', dated 20.02.2014 and numbered 9 and additionally professional teaching fields which had given in 'Journal of Communiques' of 'Ministry of National Education', dated August 2014 and numbered 2683; the procudures and the principles of the 'Pedagogical Formation Training Certificate Program' which has published by the 'Council of Higher Education' for the teacher candidates who have graduated from the faculties and have graduated from the fields which has given in the 'Journal of Communiques', expressed that 'Instructional Technologies and Material Design' lesson shall be a compulsory lesson and shall be applied from the fall semester of 2014-2015 (YÖK, 2014). (http://www.yok.gov.tr/web/guest/icerik/-/journal_content/56_INSTANCE_rEHF8BIsfYRx/10279/7052802). 
Different researchers (Angeli, 2005; Park \& Young, 2013; Yeh \& Cheng, 2010) have reached the conclusion about the use of various technological items and computer programs in teacher training programs such as 'Pedagogical Formation Training Certificate Program' that teacher candidates have increased their proficiency in using technology and their quickness.

In this context, 'Instructional Technology and Material Design' lesson that every teacher candidates should learn, is very important for enriching the lesson with different materials, technological items and computer programs to make the permanent achievement.

This need is supported by the findings of Kurtdede-Fidan's (2008) research which reveal the level of use of instructional technologies by the teacher candidates in Turkey is insufficient. Nevertheless, in their research teacher candidates have expressed their beliefs that integrating instruction with tools have provided productive and effective instruction, permanent and fun learning, active participation, increased attention to the lesson and transferred of learned information to everyday life.

Similarly, Postholm (2007) emphasizes that the use of information and communication technologies in the classroom environment is more useful than other alternative items, and that teachers have an important role in enhancing and increasing the benefits of information communication technologies. However, the use of instructional technologies in our country is rather inadequate compared to abroad.

Crook et al. (2008) found in their research which is conducted by secondary school teachers that $75.2 \%$ of teachers use web 2.0 technologies and 32\% use these technologies in their classrooms. However, web 2.0 technologies are still being recognized by teachers and teacher candidates, and efforts should be made to spread the educational use.

Horzum (2010) also supports this idea with the conclusion that primary school teachers of the 'Ministry of National Education' in Turkey do not have a high awareness of web 2.0 tools and their educational use is not widespread.

The 'Instructional Technologies and Material Design' lesson, which is provided within the scope of the 'Pedagogical Formation Training Certificate Program' which is active in the education of the teachers in Turkey, tries to improve the adequacy of instructional technologies and materials of teacher candidates. In this context it is very important to take the opinions of qualified teacher candidates which will give insight into the level of knowledge and skills in using instructional technologies and materials in the teaching process.

For the stated reasons, it was aimed to examine the opinions of the teacher candidates who have been taken 'Instructional Technology and Material Design' lesson in the 'Pedagogical Formation Training Certificate Program' which is a pre-service teacher training program and have been practiced learning outputs of this lesson in other practical instruction lessons and in their lectures in the teaching internship school, about the using of instructional technologies and materials in 2015-2016 academic year.

\section{Method}

Phenomenology studies are accomplished in order to define the common meaning of the experiences of a few people related to a phenomenon or a concept (Creswell, 2016). In this context, it is aimed to determine the experiences of teacher candidates about teaching techniques and materials, to determine their opinions about usage and the ways of giving place in education by integrating them with different activities in their fields.

For this purpose, the opinions of the teachers candidates who have been taken 'Instructional Technology and Material Design' lesson in the 'Pedagogical Formation Training Certificate Program' and have been practiced learning outputs of this lesson in other practical instruction lessons in the 'Pedagogical Formation Training Certificate Program' and in their lectures at the teaching internship school, were taken by writing. Thus, teacher candidates have experienced the hand-design instructional materials and instructional technologies which they have learned in ' Instructional Technology and Material Design' lesson, in their lectures at their teaching internship school and other practical instruction lessons in 'Pedagogical Formation Training Certificate Program' such as an education program for teacher candidates. In addition the study is a qualitative study such as phenomenon study. The phenomenon study has been selected in order to investigate what, why and how are the similarities and differences between the experiences and in the experiences of every teacher candidates. In this regard the opinions of the volunteers were taken from utilizing nine semi-structured open-ended questions. Datas were collected in writing in fifty minutes and were given personel numbers. The records are also transferred to the computer environment in the form of written texts. Datas were analyzed by content analysis and analyzed in three steps which are expressed by Miles and Huberman (1984) as data reduction, visualization the data, results and confirmation. As Altunışık and et. al (2010) expressed, try to define data by content analysis; the data that are similar to each other and related to each other are interpreted by being put together in the frame of certain concepts and themes. Contents of the participants' opinions are systematically defined by content analysis. In this context, for analysis datas of this study, the data are divided into categories by comparing the similarities and differences between the expressions of the individuals have participated in the study. The themes 
were created by moving from categories. The themes and categories were checked with the available data. The obtained data were reviewed for the second time and the existing categories and themes were checked and continued to be changed. This process has been maintained until the categories and the themes that have been created match up with the data obtained in the study. The categories and themes obtained by the analysis were then prepared in the form of logical and hierarchical mind maps, each with its own phenomenon, with using the inspiration 9.2 program. In addition, discrimination has been tried to be reflected in understanding the phenomenon. Finally, participants' perceptions of the topic were interpreted.

For the internal validity of the study, the processes of collecting, analyzing and interpreting the data are consistent. The research reflects the social realities of the participants who has been involved in the study. Links between the categories has been intensified to increase the internal validity of the study.

For the external validity of the study, the data sources of the research, the collection of the data and the analysis of the data has been explained. The results of this research are generalizable to similar environments and situations.

The data obtained for the internal reliability of the study has been presented to the reader without comment. The data were evaluated independently by another expert in the field and the results were compared.

For the external reliability of the study, the characteristics of the participants, who were the data source of the research, has been clearly presented. Only open identities has not been included. The conceptual framework which has been used in the analysis of the obtained data has been defined. Data collection and analysis processes has been explained.

\subsection{Participant Characteristics}

In consequence of the participants are in the 'Pedagogical Formation Training Certificate Program' which has been running in a state university in Turkey. The participants are identified with purposeful sampling. Purposeful sampling is the selection of rich situations in terms of information in limited resources in the context of the purpose of the study in order to conduct in-depth research, (Patton, 2002). According to this sampling method, the sample was selected by the criterion sampling technique. Criterion sampling was done to be identify the persons who have the qualifications that was determined in relation to the problem. In criterion sampling, the selected sample refers to the case where it represents people who have experienced the phenomenon (Cresswell \& Poth , 2017). In this context, the opinions of the teacher candidates who have been taken 'Instructional Technology and Material Design' lesson in the 'Pedagogical Formation Training Certificate Program' which is a pre-service teacher training program and have been practiced learning outputs of this lesson in other practical instruction lessons and in their lectures in the teaching internship school for one semester, on the other hand teacher candidates who have experienced in the using of instructional technologies and materials which they learned in 'İnstructional Technology and Material Design", were taken after practice experiences at the end of the semester. Seventeen female and eight male in both environments, in total twenty five participants The ages of the participants within the group heterogeneous between twenty two and thirty five. Table 1 shows the participants' features.

Table 1. Participants' features

\begin{tabular}{lll}
\hline Participant number & Gender & Study Field \\
\hline T1 & Male & Turkish Language and Literature \\
T2 & Male & Turkish Language and Literature \\
T3 & Female & Turkish Language and Literature \\
T4 & Male & Accommodation and Travel \\
T5 & Male & Turkish Language and Literature \\
T6 & Male & History \\
T7 & Male & Turkish Language and Literature \\
T8 & Female & Health Sciences \\
T9 & Female & Accommodation and Travel \\
T10 & Female & Turkish Language and Literature \\
T11 & Male & Accommodation and Travel \\
T12 & Female & Health Sciences \\
T13 & Female & Health Sciences \\
14 & Female & Mathematics \\
T15 & Female & Accommodation and Travel \\
T16 & Female & Chemistry \\
T18 & Female & Health Sciences \\
T19 & Female & Accommodation and Travel \\
T20 & Female & Turkish Language and Literature \\
T21 & Female & History \\
T22 & Female & Turkish Language and Literature \\
T23 & Female & Turkish Language and Literature \\
T24 & Female & History \\
T25 & Male & Chemistry \\
\hline
\end{tabular}

As seen in Table 1, 9 of the 25 teacher candidates are studying in Turkish Language and Literature, 3 are studying in 
Chemistry, 1 is studying in Mathematics, 3 is studying in History, 5 is studying in Accommodation and Travel, 4 is studying in Health Sciences. In this context, 17 are from Social Sciences, 4 from Science and Mathematics, and 4 from Health Sciences.

The categories and themes generated from the data obtained from the participants in the specified feature are presented in Table 2.

Table 2. Categories and themes

- $\quad$ Preferences about using instructional materials

- The advantages of using instructional materials

- Preferences about using instructional technologies

- The advantages of using instructional technologies

- The advantages of using instructional materials and technologies in the lesson stages

- Creativity activities

- Measuring and evaluating

- Introduction

- Implementation

- The use of instructional materials and technologies in each case

- The purpose of using instructional materials and technologies in instruction process

- Self-efficacy of instructional technologies usage

- Recommendations about the 'instructional technologies and material design' lesson

\section{Findings}

\subsection{Teacher Candidates' Preferences about Using Instructional Materials}

The mind map of teacher candidates regarding the preferences about using instructional materials are presented in Figure 1.

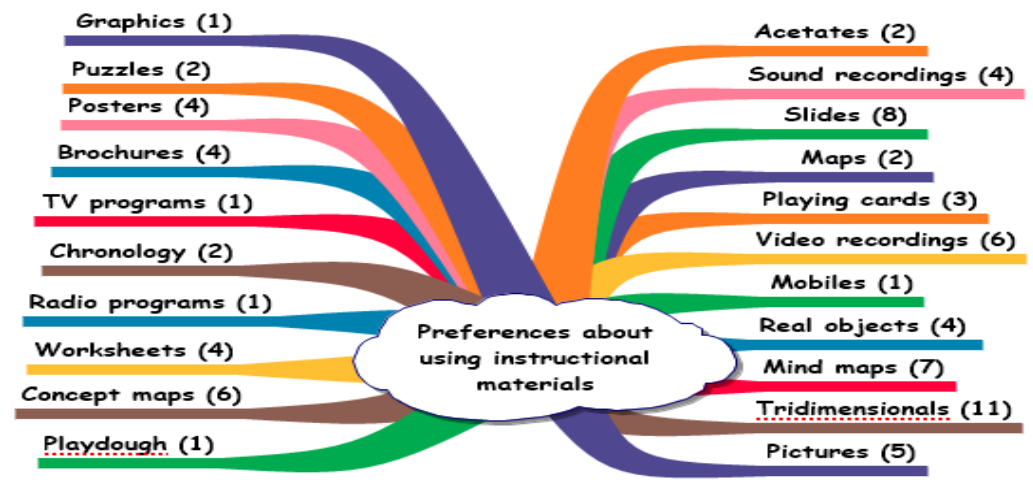

Figure 1. The preferences about using instructional material

As seen in Figure 1, most of teacher candidates prefere several instructional materials regarding two dimensionals as graphics, puzzles, posters, brochures, chronologies, playing cards, worksheets, acetates, maps, pictures, concept and mind maps. However they prefer tridimensionals as real objects, mobiles, playdough. In addition they prefer to use recordings, slides and programs of TV and radio. A stunning opinion regarding these preferences is as below:

T7: Concept and mind maps were the most beautiful materials in my field, especially for Anonymous Folk Literature lesson. When I was telling about Karagöz which is a kind of Turkish traditional theatre, I paid attention for preparing puppets, making curtains, compatible puppet design with the original. Thus, I think that the visual impression created with the help of materials ensured permanency. I used panels for New Turkish Literature and Language-Teaching lessons. I also made banners and made materials for students to remember.

\subsection{Teacher Candidates' Opinions about the Advantages of Using Instructional Materials}

The mind map of teacher candidates' opinions about the advantages of using instructional materials are presented in Figure 2. 


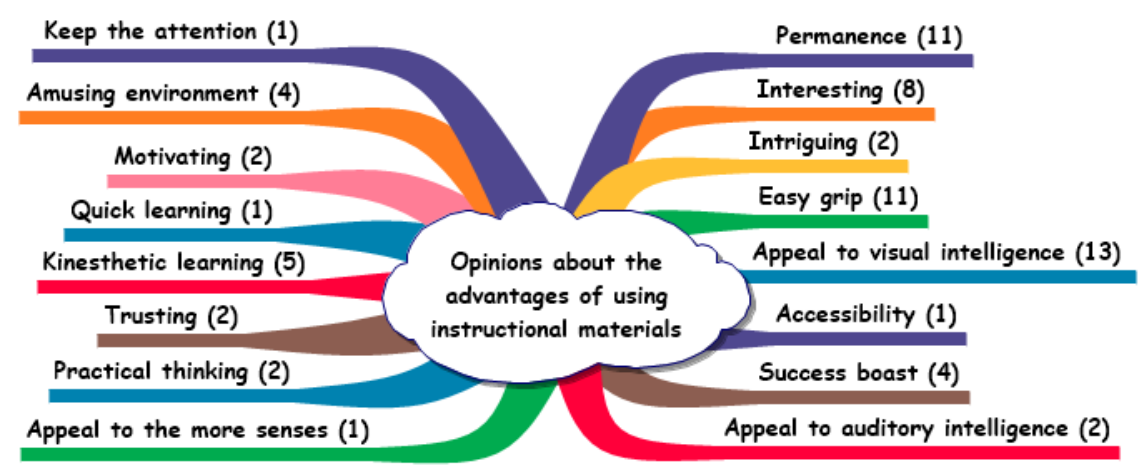

Figure 2. The opinions about the advantages of using instructional materials

As seen in Figure 2, most of teacher candidates think to use several instructional materials has some advantages regarding skills such as kinesthetic, visual, auditory, thinking, motivation, quick learning. In addition they point that using instructional materials is interesting, intriguing, creating an amusing environment and providing permanent. They stated appealing to visual intelligence as an advantage mostly. Some stunning opinions regarding these opinions are as below:

T10: Every student has a learning style. Some students understand better by images but some understand better by sounds or touches. Addressing the three-in-one during instruction process helps to make learning faster. When material design was qualified, students picked and choosed the appropriate part, so learning became easier and faster.

T13: The health field is a practice-based area, so when we used more material, instruction became more useful for students. When they will enter the hospital environment, they have seen, and have known all of the materials which they will meet in the hospital. So as a result of integrated instruction with the materials, I think they will adapt to their professional life easily.

T8: I think that it is useful for ensuring the permanence of the subject, grasping the subject, making meaning, attracting the attention of the students, motivating and relating the subjects.

\subsection{Teacher Candidates' Preferences about Using Instructional Technologies}

The mind map of teacher candidates' preferences about using instructional technologies are presented in Figure 3.

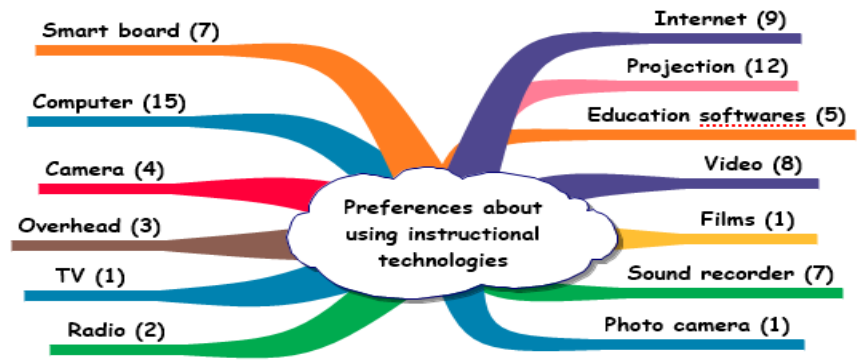

Figure 3. Preferences about using instructional technologies

As seen in Figure 3, most of teacher candidates prefere several instructional technologies regarding computer such as internet, education softwares, in addition smart board, camera, overhead, TV, radio, video, projection, films, sound recorder and photo camera. They stated the computer mostly. Some stunning opinions regarding these preferences are as below:

T3: All topics are suitable for slide and projection use in history lessons. I mostly used slides. In particular, my slides also included exam questions that are included in exams made throughout the country. When I was teaching a topic, I provided reinforcement with the questions.

T8: I think that the use of computers, slide presentations, videos, concepts and mind maps were appropriate for the use of educational technology in the health field.

T10: I could teach epics and theaters that integrated with films and videos in the field of literature. It was more permanent and effective when I played poems instead of reading them. I could also address the visual intelligence of the students by preparing slides. 


\subsection{Teacher Candidates' Opinions about the Advantages of Using Instructional Technologies}

The mind map of teacher candidates' opinions about the advantages of using instructional technologies are presented in Figure 4.

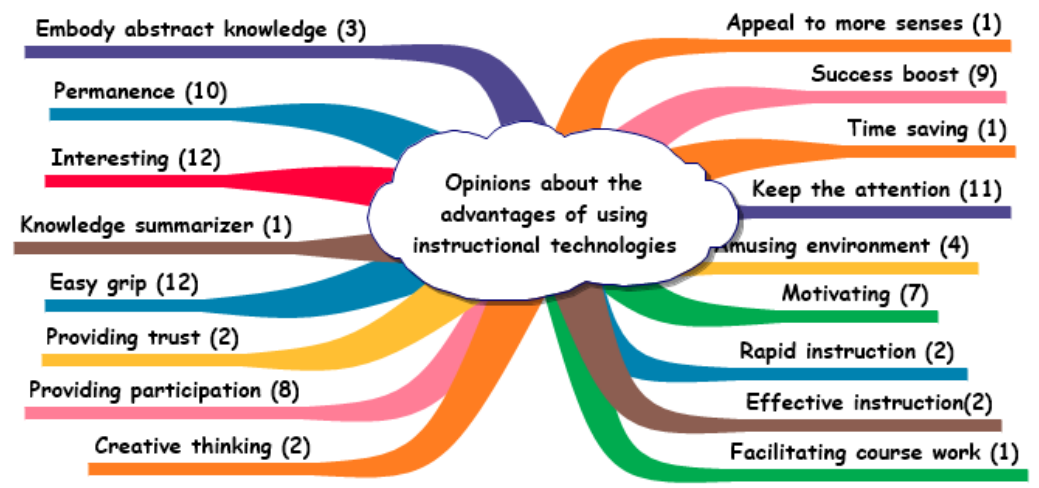

Figure 4. Opinions about the advantages of using instructional technologies

As seen in Figure 4, most of teacher candidates think to use several instructional technologies has some advantages regarding skills such as creativity, motivation, summarizing and gripping. On the other hand, they stated that instructional technologies are useful for providing trust, rapid and effective instruction, saving time, increasing success, keeping the attention and facilitating lesson work. Also using instructional technologies are likely to address more senses. They have the role of creating amusing environment, embodying abstract knowledge and providing permanent. They stated attracting interest and keeping the attention to the lesson as advantages mostly. Some stunning opinions regarding these opinions are as below:

T10: Today, technology is developing fastly. The new generation takes care of every tasks with technology. For this reason, teachers should use educational technology. Accordingly, they should address their students. I saw that the greatest effect of the teaching-learning technologies was on attention. Students preferred visual and sound assisted materials instead of plain and straight expression.

T1: Instruction which was integrated with instruction technologies, was fun and facilitated learning for students. Additionally instructional technologies provided permanency.

3.5 Teacher Candidates' Opinions about the Advantages of Using Instructional Materials and Technologies in the Lesson Stages

The mind map of teacher candidates' opinions about the advantages of using instructional materials and technologies in the lesson stages are presented in Figure 5.

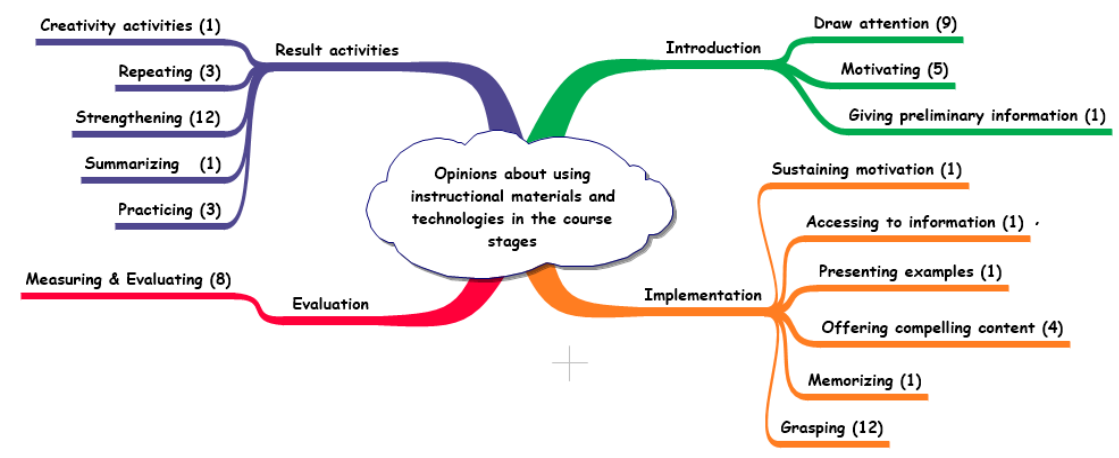

Figure 5. Opinions about using instructional materials and technologies in the lesson stages

As seen in Figure 5, most of teacher candidates stated the several instructional materials and technologies in the lesson stages regarding introduction activities as drawing attention, motivating, giving preliminary information. In this stage, they stated drawing attention mostly. On the other hand, teacher candidates emphasized the using instructional materials and technologies in the implementation stage for sustaining motivation, accessing to information, presenting examples, offering compelling content, memorizing and grasping. In this stage, they stated grasping mostly. However, teacher candidates' purposes of using materials and technologies in the lesson stage of result activities are repeating, strengthening, summarizing, practicing and creativity activities. In this stage they stated strengthening mostly. Also they stated measuring and evaluating in the course stage of evaluation. A stunning opinion regarding these opinions is as follows: 
T10: I used instructional technologies to attract attention and motivation at the entrance of my lessons. But in some cases I used them for the development part of the lessons.

T8: At the introduction of the lesson, I used instructional technologies for attracting the attention, motivating students for topics. At the end of the lesson, I used them for summarizing with the purpose of strengthening the topics. So permanency was provided.

T9: At the introduction part of the lesson, I used them to draw attention to the subject, at the development part of the lesson I used them for the conception of the students and at the end of the lesson, I used them for measuaring and evaluating the knowledge that given in the lesson.

\subsection{Teacher Candidates' Opinions on the Use of Instructional Materials and Technologies in Each Case}

The mind map of teacher candidates' opinions on the use of instructional materials and technologies in each case are presented in Figure 6.

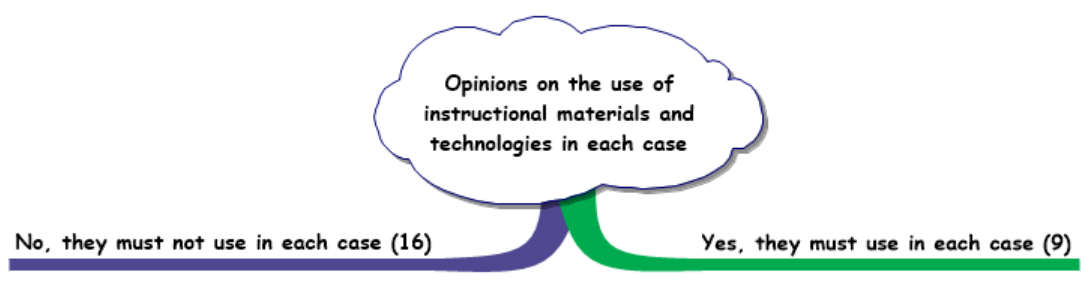

Figure 6. Opinions on the use of instructional materials and technologies in each case

As seen in Figure 6, most of teacher candidates think that instructional materials and technologies must not use in each case. A stunning opinion regarding these opinion is as follows:

T4: I preferred to use instructional technologies in subjects that were difficult to understand and in subjects where the student was very strange. In such cases, we can use of the instructional technologies to make the students learn better.

T5: I did not think about using instructional technologies in every subject. Because some subjects were boring and some students limited a lesson to only a boring topic and said "I am bored very much and I do not like this lesson". So they regarded the lesson as boring. I used instructional technologies to break molds in these matters.

T3: I did not find it appropriate to use instructional technologies in the processing of each subject. Because there was no need to use materials in some subjects. For example, there were also some subjects that could be understood only through the lesson notes. I found it more appropriate to explain the subjects with instructional technologies, that cause confusion to understand compared to other subjects. I think if we use in all areas, students will accustomed to it and after a certain time they will perceive it as a normal lesson which do not be used instructional technology, so they will not pay attention, they will not worry.

\subsection{Teacher Candidates' Opinions on the Purpose of Using Instructional Materials and Technologies in Instruction} Process

The mind map of teacher candidates' opinions on the purpose of using instructional materials and technologies in instruction process are presented in Figure 7.

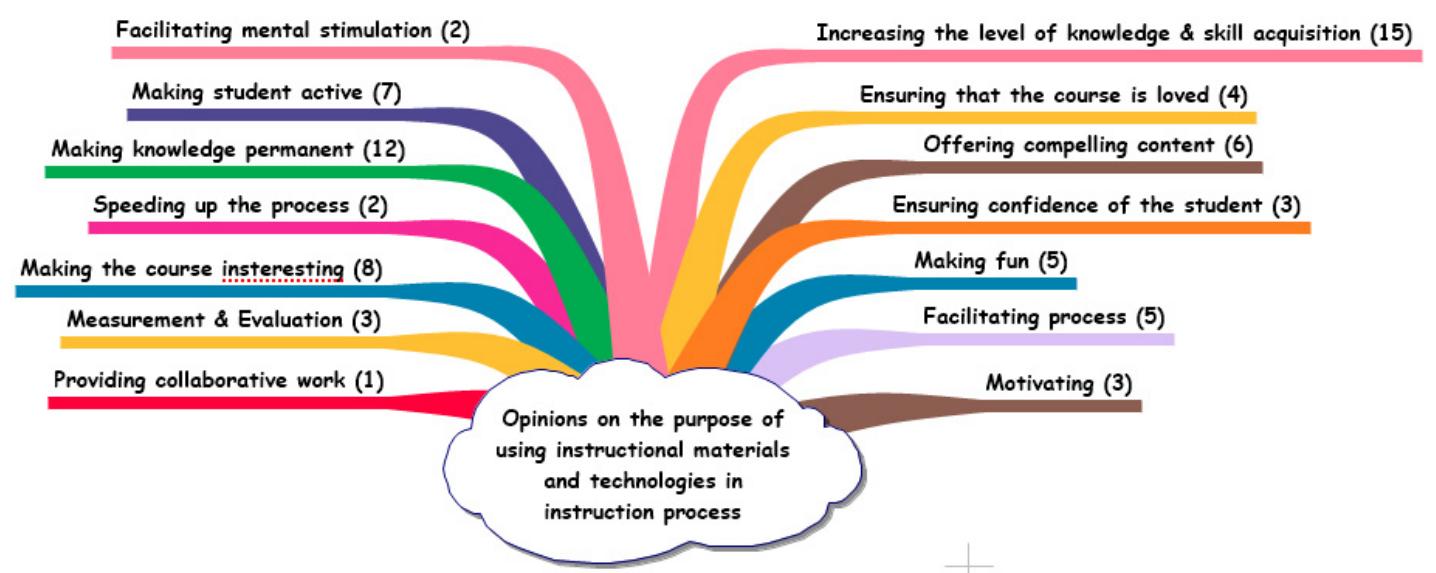

Figure 7. Opinions on the purposes of using instructional materials and technologies in instruction process 
As seen in Figure 7, most of teacher candidates emphasized the purposes as facilitating mental stimulation, making student active, making knowledge permanent, speeding up the process, making the lesson interesting, providing collaborative work, increasing the level of knowledge and skill acquisition, ensuring that the lesson is loved, offering compelling content, ensuring confidence of the student, making fun, facilitating process, motivating, measuring and evaluating. They stated the purpose of increasing the level of knowledge and skill acquisition mostly.

T1: Even if it takes time to prepare instructional materials and technologies, they were also used to speed up the lesson process, to facilitate lecturing, to make the lesson fun for the student, to allow every student to attend the lesson, to make the information become permanent.

T15: I used them to consolidate the information, to understand if the subjects were understood, to take care of it, to ensure that the lesson is loved, to activate the students, to ask questions.

\subsection{Teacher Candidates' Opinions on Self-efficacy of Instructional Technologies Usage}

The mind map of teacher candidates' opinions on self-efficacy of instructional technologies usage are presented in Figure 8 .

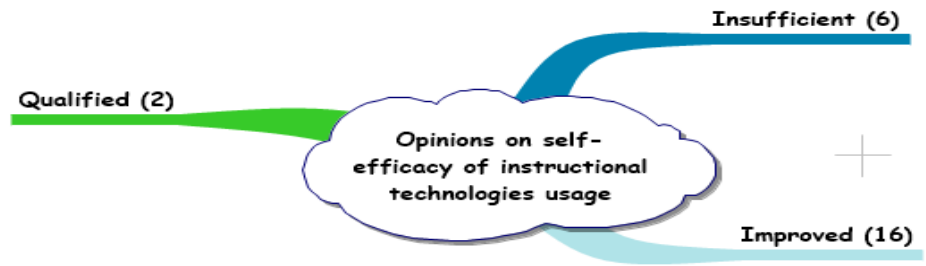

Figure 8. Opinions on self efficacy of instructional technology usage

As seen in Figure 8, most of teacher candidates has low beliefs about their self-efficacy. They think that they must improve the ability of using instructional technologies.

T2: I used instructional technologies in my lectures at the school where I did my internship. I can not say I'm very good about technological tools. But, of course, now that we have started to use the technological tools in our schools, so I have to close the gap in this regard.

T15: I am moderately competent in using instructional technologies and I think to develop my abilities. Because I want to put out new ideas, draw attention of my students and leave permanent traces and information on them.

T9: I do not know much about computer programs. I referred more to the use of computer graphics, concept maps, work papers, slides, play cards for enabling active participation, and computer contests for recreating and comprehending information. I have learned and practiced preparing digital mind maps and three-dimensional materials in instructional technologies and material design lesson of 'Pedagogical Formation Training Certificate Program' as teacher training program.

\subsection{Teacher Candidates' Recommendations about the 'Instructional Technologies and Material Design' Lesson}

The mind map of teacher candidates' recommendations about the 'instructional technologies and material design' lesson are presented in Figure 9.

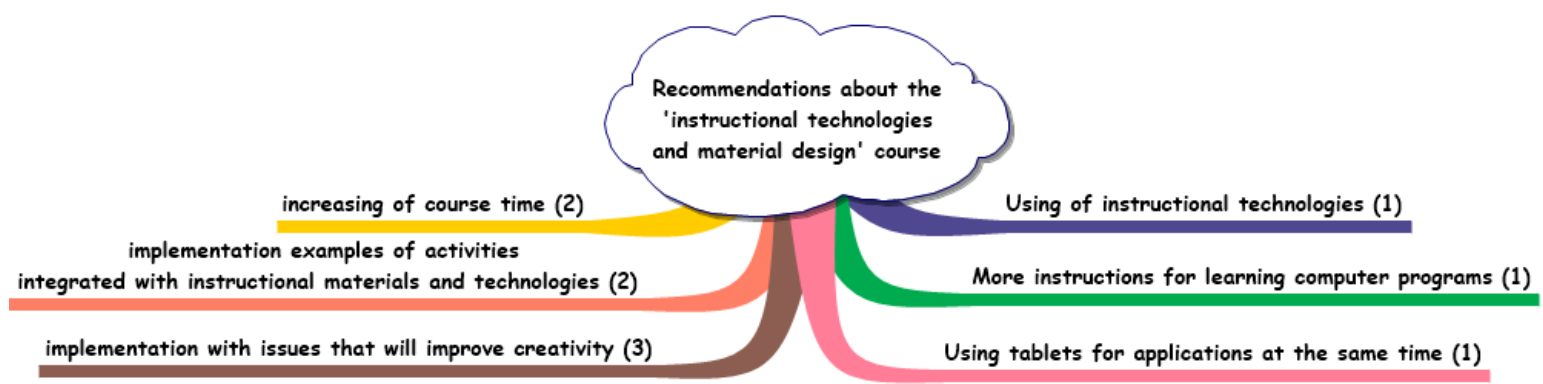

Figure 9. Teacher candidates' recommendations for 'instructional technologies and material design' lesson in 'pedagogical formation training certificate program' for training teachers

As seen in Figure 9, teacher candidates recommend several activities for instructional technologies and material design' lesson such as increasing of lesson time, implementing examples of activities integrated with instructional materials and technologies, implementing with issues that will improve creativity, teaching and practicing the usage of instructional technologies, using tablets for applications at the same time, making more instruction for learning computer programs. 
They stated implementing with issues that will improve creativity mostly.

T9: I think that everybody who is going to be a teacher and who is teaching and who has not taken instructional technologies and material design lesson, should take this lesson. After this lesson has been taken, our own point of view about teaching has changed. We were developed our creativity together with the students when we practiced the instructional technologies and materials in our instructional processes.

T10: I was not aware of the instructional materials before I took this lesson. I do not remember my teachers such as preparing different materials during my own student life. Instructional technologies and material design lesson is definitely very useful for teacher candidates. We learned to address each student. This lesson taught to plan and implement more permanent and effective lesson. Additionally the lessons that instructional technologies and materials used, taught our students to interact in different ways. But there was a problem that the duration of this lesson was not enough, it should be increased. I think if teachers use the materials and technologies effectively, it will be possible to provide a good instruction.

\section{Discussion, Conclusion and Recommendations}

Teacher candidates expressed that they could use many different materials in two and three dimensions during the instruction process. They mentioned graphics, puzzles, posters, brochures, chronologies, playing cards, worksheets, acetates, maps, pictures, concept and mind maps as two dimensionals instructional materials. On the other hand they pointed real objects, mobiles, playdough as three dimensional instructional materials. However they stated to use recordings and programs of TV and radio as instructional materials.

Different researchers have talked about the benefits of teaching materials, such as the films (Kaya \& Çengelci, 2011), concept maps (Simper, Reeve \& Kirby, 2016), graphics (Apperson, Laws \& Scepansky, 2006), slides (Bangir-Alpan, 2013; Bartsch \& Cobern, 2003; Susskind, 2005) that indicated by teacher candidates in the instructional process.

However in this study, teacher candidates indicated that they could use the most hand made three dimensional materials in teaching. Similarly, in the research of Yanpar et al. (2006), teacher candidates have emphasized the importance of using hand-made two-dimensional and three-dimensional instructional materials which are made by hand, also have indicated that they found them more creative, original and multipurpose instructional materials than which are prepared in computer. In addition, different researchers (Adigüzel, 2010; Cengizhan, 2011) stated that the written and printed materials as most used materials, and the audiovisual tools such as TV and radio programs as least used materials in the instructional process as seen in the results of this research. In addition, different researchers (Kazu \& Yeşilyurt, 2008; Uçar, 1999) have found that the use of materials in the instructional process is inadequate.

Teacher candidates stated the advantages of using several instructional materials regarding skills such as kinesthetic, visual, auditory, thinking, motivation, quick learning. Aydin and Yilmaz (2010) found that the use of structured instructional materials improved the students' upper level cognitive skills. Also, Choi and Johnson (2010) found that video use increased motivation compared to the printed material. In addition they point that using instructional materials is interesting, intriguing, creating an amusing environment and providing permanent. They stated appealing to visual intelligence as an advantage mostly. Likewise, most of the teacher candidates who were participated in Özer and Tunca's (2014) research, stated that they could use the materials that they prepared in the ' Instructional Technologies and Material Design' lesson when they will start to work as teachers because the materials facilitates learning, provides permanent learning, reinforces knowledge, increases class participation and addresses to many sensory organs.

However most of teacher candidates prefere several instructional technologies, especially they stated the computer mostly. Similarly, different researchers (Baki et al., 2009; Yeşilyurt, 2006) have also found that the instructional technology which is most used by teachers and teacher candidates is computer.

Most of teacher candidates think to use several instructional technologies has some advantages regarding skills such as creativity, motivation, summarizing and gripping. On the other hand, they stated that instructional technologies are useful for providing trust, rapid and effective instruction, saving time, increasing success, facilitating lesson. They stated attracting interest and keeping the attention to the lesson as advantages mostly. Different researchers have reached similar findings (Güneş \& Aydoğdu-İskenderoğlu, 2014, Kolburan-Geçer, 2010, Sönmez and et al., 2006, Güven, 2006).

Most of teacher candidates stated the several instructional materials and technologies in the lesson stages regarding introduction activities, they stated drawing attention mostly. On the other hand, in the implementation, they stated grasping mostly. However, in the result activities, they stated strengthening mostly. Also they stated measuring and evaluating in the lesson stage of evaluation. Likewise, Yazar (2015) and Özer and Tunca (2014) found the teacher candidates' aims to use instructional materials and technologies as to attract attention, increase interest and persistence in the classroom. 
In addition most of teacher candidates think that instructional materials and technologies must not use in each case of the lesson. Also most of teacher candidates emphasized many purposes, especially they stated the purpose of increasing the level of knowledge and skill acquisition mostly. Also Tomei (2013) expressed that teachers develop a wide range of $21^{\text {st }}$ century skills such as global awareness, individual learning, literacy in information and communication technologies, problem solving skills, time management and personal responsibility, lifelong learning, financial, economic, entrepreneurial literacy, business and collaborative skills via using instructional technologies and materials.

Most of teacher candidates has low beliefs about their self-efficacy. They think that they must improve the ability of using instructional technologies. Likewise, Adigüzel (2010) found that teachers were more likely to use written and printed traditional materials, and they were less familiar with instructional technologies and were not willing to develop skills to use new instructional technologies. Similarly, Stosic (2015) stated that teachers have inadequate skills for using instructional technologies.

Teacher candidates recommend several activities for 'instructional technologies and material design' lesson, especialy they stated implementing with issues that will improve creativity mostly. Güneş and Aydoğdu-İskenderoğlu (2014) have found many benefits of 'instructional technologies and material design' lesson for teacher candidates.

Also in this study, teacher candidates pointed out that the most contribution of the lesson is to gain teaching experience and teaching sense. Additionally they expressed that instructional methods knowledge, material and design knowledge, learning principles, personal development, creativity, effective presentation, classroom management, computer usage knowledge, extensive thinking, research skills as other gains of the lesson.

Belong to the conclusions, some recommendations can be brought. For improving teacher candidates; instructional technology and material design lesson should be integrated into the teaching field. As teacher candidates' competencies to integrate web 2.0 technologies with teaching can be developed, the ability to prepare hand materials can also be improved. In instructional technologies and material design lessons, the time allocated for implementation can be increased. Teaching technologies and material use can be appropriately developed to enhance high-level thinking skills. Competency can be gained for the usage of instructional technologies and materials in order to be able to take place at certain stages of the lesson. 'Instructional technology and material design' lesson can include the latest instructional technologies. Educational faculties can be equipped with different instructional technologies and these technologies can be used in training of teacher candidates.

For further research; the competency of teacher candidates can be put forth for the usage of instructional technologies. Content inspection of instructional technologies and materials usage in different universities can be done. Teacher candidates who have taken up instructional technologies and material design lesson with increased application rate, the effectiveness of the teaching process and the experiences of the participants can be put forth when they start their profession.

\section{References}

Adıgüzel, A. (2010). The status of instructional technology in the primary schools and classroom teachers' level of using these technologies. Dicle University Journal of Ziya Gökalp Faculty of Education, 15, 1-17.

Altun, A. (2005). Developing technologies and new literacy. Ankara: Anı Publishing.

Altunışı, R., Coşkun, R., Bayraktaroğlu, S., \& Yıldırım, E. (2010). Research methods in social sciences. Practiced SPSS. Sakarya: Sakarya Publishing.

Angeli, C. (2005). Transforming a teacher education method course through technology: Effects on pre-service teachers' technology competency. Computers \& Education, 45(4), 383-398. https://doi.org/10.1016/j.compedu.2004.06.002

Apperson, J. M., Laws, E. L., \& Scepansky, J. A. (2006). The impact of presentation graphics on students' experience in the classroom. Computers \& Education, 47(1), 116-126. https://doi.org/10.1016/j.compedu.2004.09.003

Aydın, N., \& Yılmaz, A. (2010). The effect of constructivist approach in chemistry education on students' higher order cognitive skills. H. U. Journal of Education, 39, 57-68.

Baki, A., Aydın-Yalçınkaya, H., Özpınar, İ., \& Çalık-Uzun, S. (2009). Comparing views of primary school mathematics teachers and prospective mathematics teachers about instructional technologies. Turkish Journal of Computer and Mathematics Education, 1(1), 65-83.

Bangir-Alpan, G. (2013). A critical point of view to the courses with powerpoint: Students' opinions. H. U. Journal of Education, 44, 61-72.

Bartsch, R. A., \& Cobern, K. M. (2003). Effectiveness of powerpoint presentations in lectures. Computers \& Education, 41(1), 77-86. https://doi.org/10.1016/S0360-1315(03)00027-7 
Baylor, A. L., \& Ritchie, D. (2002). What factors facilitate teacher skill, teacher morale, and perceived student learning in technology-using classrooms? Computers \& Education, 39(4), 395-414. https://doi.org/10.1016/S0360-1315(02)00075-1

Cengizhan, S. (2011). Effective use of instructional materials and technologies in teacher training: Expectations and opinions of teacher candidates. International Online Journal of Educational Sciences, 3(2), 641-662.

Ceyhan, E. (2007). Foreing language instructional technology. İstanbul: Morpa Kültür Publishing.

Choi, H. J., \& Johnson, S. D. (2010). The effect of context-based video instruction on learning and motivation in online courses. American Journal of Distance Education, 19(4), 215-227. https://doi.org/10.1207/s15389286ajde1904_3

Creswell, J. W. (2016). Qualitative research design: Qualitative research and research design based on five approaches, (translator Eds.) M. Butun \& S. B. Demir. Ankara: Siyasal Publishing.

Creswell, J. W., \& Poth, C. N. (2017). Qualitative Inquiry Research Design. Thousand Oaks, CA: Sage.

Christensen, C. M., Horn, M. B., \& Johnson, C. W. (2008). Disrupting class. How disruptive innovation will change the way the world learns. Mc Graw Hill. Retrieved from http://vedpuriswar.org/Book_Review/Learning/Disrupting\%20Class.pdf

Crook, C., Fisher, T., Graber, R., Harrison, C., Lewin, C., \& Cummings, J. (2008). Implementing Web 2.0 in secondary schools: Impacts, barriers, and issues. Retrieved from http://www.radford.edu/mdunleavy/620/Syllabus_files/web2_technologies_learning.doc

De Lay, A. M. (2010). Technology as a differentiated instruction tool. The Agricultural Education Magazine, 83(3). Retrieved from https://www.questia.com/library/journal/1P3-2224323211/technology-as-a-differentiated-instruction-tool

Duffy, T. M., \& Jonassen, D. H. (1992). Constructivism and the technology of instruction: A Conversation. New Jersey: Lawrence Erlbaum Associates Publishers.

Ekici, G. (Ed.)(2014). Instructional technologies and material design. Edirne: Paradigma Academia Publishing.

Gagne, R. M. (2010). Instructional technology foundations. New York: Routledge.

Grasha, A. F., \& Yangarber-Hicks, N. (2000). Integrating teaching styles and learning styles with instructional technology. College Teaching, 48(1), 2-10. https://doi.org/10.1080/87567550009596080

Güneş, G., \& Aydoğdu-İskenderoğlu, T. (2014). Attitudes of pre-Service primary school mathematics teachers towards instructional technologies and material design lesson. GEFAD/GUJGEF, 34(3), 469-488.

Güven, S. (2006). The evaluation of teaching technologies and materials development course in terms of competencies it provides (A sample of İönü University Faculty of Education). Gazi University Journal of Turkish Education Sciences, 4(2), 1-16.

Horzum, M. B. (2010). Investigating teachers' Web 2.0 tools awareness, frequency and purposes of usage in terms of different variables. International Journal of Human Sciences, 7(1), 603-633.

Kaya, E., \& Çengelci, T. (2011). Pre-Service Teachers' Opinions Regarding Using Films in Social Studies Education. Journal of Social Studies Education Research, 2(1), 116-135.

Kazu, H., \& Yeşilyurt, E. (2008). Teachers' aims of using instructional tools and materials. Firat University Journal of Social Sciences, 18(2), 175-188.

Kolburan, G. A. (2010). Experience of teachnical teacher candidates towards teaching technologies and material development course. Yüzüncü Yıl University Journal of Education Faculty, 7(2), 1-25.

Kurtdede-Fidan, N. (2008). Teachers' views with regard to the use of tools and materials in the primary level. The Journal of Theoretical Educational Science, 1(1), 48-61.

Miles, M. B., \& Huberman, A. M. (1984). Qualitative data analysis: A source book of new methods. London: Sage.

Sarıçoban, A., \& Tavil, Z. M. (Ed). (2012). Instructional technologies and material design in foreign language instruction. Ankara: Anı Publishing.

Sever, R. (2011). Instructional technologies and material design. Design examples. Ankara: Anı Publishing.

Simper, N., Reeve, R., \& Kirby, J. R. (2016). Effects of concept mapping on creativity in photo stories. Creativity Research Journal, 28(1), 46-51. https://doi.org/10.1080/10400419.2016.1125263

Özer, Ö., \& Tunca, N. (2014). The opinion of pre-service teachers towards preparating and using of materials. Route Educational and Social Science Journal, 1(3), 214-229. https://doi.org/10.17121/ressjournal.130 
Park, Y. J., \& Yang, Y. (2013). Pre-service teachers' perception of and technology competency at creating and using e-picture books. International Education Studies, 6(4), 124-133. https://doi.org/10.5539/ies.v6n4p124

Postholm, M. B. (2007). The advantages and disadvantages of using ICT as a mediating artefact in classrooms compared to alternative tools. Teachers \& Teaching, 13(6), 587-599. https://doi.org/10.1080/13540600701683531

Patton, M. Q. (2002). Qualitative research and evaluation methods. Thousand Oaks, CA: Sage.

Sönmez, E., Dilber, R., Alver, B., Aksakallı, A., \& Karaman, İ. (2006). An investigatian towards important or the instructian technology and material development lesson. Atatürk University Journal of Kazım Karabekir Educational Faculty, 13, 113-119.

Stosic, L. (2015). The importance of educational technology in teaching. International Journal of Cognitive Research in Science, Engineering and Education, 3(1). Retrieved from http://ijcrsee.com/index.php/ijcrsee/article/view/166/316

Susskind, J. E. (2005). Powerpoint's power in the classroom: Enhancing students' self-efficacy and attitudes. Computers\&Education, 45(2), 203-215. https://doi.org/10.1016/j.compedu.2004.07.005

Tomei, L. A. (2013). Top 10 technologies for designing $21^{\text {st }}$ century instruction. International Journal of Information\& Communication Technology Education, 9(3), 80-93. https://doi.org/10.4018/jicte.2013070106

Uçar, M. (1998). Assessment of teacher opinions on the use of teaching materials in elementary education. Unpublished Master Dissertation. Afyon: Kocatepe University.

Yazar, T. (2015). Prospective teachers' opinions about instructional technologies and material design course. International Journal of Curriculum and Instructional Journal, 5(9), 23-34.

Yanpar, T., Koray, Ö., Parmaksız, R. Ş., \& Arslan, A. (2006). Investigation of hands-on and technology based materials prepared by preservice teachers with respect to the dimensions of creativity. Educational Administration: Theory and Practice, 45, 129-148.

Yanpar-Yelken, T. (2014). Instructional technologies and material design. Ankara: Anı Publishing.

Yeh, H., \& Cheng, Y. (2010). The influence of the instruction of visual design principles on improving pre-service teachers' visual. Computers \& Education, 54(1), 244-252. https://doi.org/10.1016/j.compedu.2009.08.008

Yeşilyurt, E. (2006). Factors affecting teachers' use of instructional equipments. Unpublished Master Dissertation. Elazığ: Frrat University Social Sciences Institute.

Yildirim, A., \& Şimsek, H.( 2011). Research methods in social sciences. Ankara: Seckin Publishing.

YÖK (2014). Pedagogical formation training certificate program procedures and principles. Retrieved from http://www.yok.gov.tr/web/guest/icerik/-/journal_content/56_INSTANCE_rEHF8BIsfYRx/10279/7052802

\section{Copyrights}

Copyright for this article is retained by the author(s), with first publication rights granted to the journal.

This is an open-access article distributed under the terms and conditions of the Creative Commons Attribution license which permits unrestricted use, distribution, and reproduction in any medium, provided the original work is properly cited. 